\title{
Aleksandra Matulewska
}

Adam Mickiewicz University in Poznań, Poland

\section{LEGAL LANGUAGES - A DIACHRONIC PERSPECTIVE}

\begin{abstract}
The aim of the article is to discuss the legal language transformations from a diachronic perspective taking into account the following factors: (i) spatial and temporal, (ii) linguistic norm changes, (iii) political, (iv) social (customs), and (v) globalization as well as (vi) EU-induced. Spatial and temporal factors include legal relations influenced by climate and the cycles of nature. Linguistic factors include spelling reforms and grammatical changes each language undergoes, for example, as a result of usage. As far as the law is concerned, normative changes can be observed when laws are amended. Other factors such as customs, usage, etc. cannot be neglected when discussing the language of the law. Analogously political correctness and usage can be observed in gender sensitive language and the introduction of such terms as chairperson instead of chairman. Social factors should not be overlooked. As a result of social changes, numerous terms have been introduced to legal lexicons in many countries starting with same-sex unions or same-sex-marriages. The socalled political correctness enforces some language changes and leads to the introduction of new terms and at the same time the abandonment of others. Consequently, some terms cease to be used and consequently become archaic. The aim of the article is to focus on diachronic changes in legal languages and present the communication problems resulting from them from intra- and interlingual perspectives.
\end{abstract}

Keywords: legal language, language evolution, legal terminology, diachronic linguistics.

\section{Introduction}

This paper is a continuation of findings already published in 2017 concerning the evolution of legal language (Matulewska 2017). Legal terms evolve together with changing realities and language usage. They are therefore arbitrary. In the wake of evolutionary and revolutionary changes of realities in which we live, legal languages need to transform as well, in either an evolutionary or a revolutionary way. Evolutionary changes usually take place during peacetime as a result of trade and through contacts 


\section{Aleksandra Matulewska}

with other countries whereas revolutionary changes occur during social upheaval, unrest, wars or colonization. Such changes also result from language evolution, as, in changing realities (for instance in the course of economic transformation, overwhelming technological progress, social changes, etc.), language users need to communicate new messages and consequently they need new signs to convey new content. As a result of such processes, the interpretation of legal reality which is encoded in legal signs is subject to diachronic and synchronic changes as well. Consequently, either new signs are coined or the meanings of pre-existing legal signs evolve.

Terminological transformations usually result in a multiplication of semantic relations. If due to, for instance, connotations one sign is replaced with another without the change of the meaning we deal with coining a synonym for an already existing sign. If the meaning is modified - either restricted or expanded - we deal with the appearance of hypernym-hyponym relation. If a new meaning is added to an already existing sign we deal with the relation of either polysemy or homonymy. The problem of the occurrence of homography cannot be ignored as well.

In this paper I will try to argue that translators must be aware of the changes in terminology in order to be able to translate legal texts efficiently as they affect the interpretation of legal texts. The methodology applied by the author includes the analysis of pertinent literature as well as terminological analysis of legal terminology from a diachronic perspective. Therefore, from the methodological perspective the paper is empirical in the first place as it focuses on the analysis of selected examples (it is a case-study of selected terms whose forms or meanings have evolved in the course of legal history). The observed terminological changes will be scrutinized taking into account the criterion of the factors leading to such transformations that is to say: (i) spatial and temporal, (ii) linguistic, (iii) social and custom-related, (iv) political, (v) globalization-related and finally (vi) EU-related ones.

\section{Spatial and temporal factors}

Spatial and temporal factors include legal relations conditioned by environmental factors such e.g. climate and cycles of nature. Therefore, in France, there is the contract of lease of vineyards which cannot be concluded earlier than the period required for a vineyard to start returning profit. The vineyard owner starts earning money only after several years from the moment of planting the first grapevines, so if someone wants to invest in such business he or she must be given reasonable time to start 
generating a profit from his or her investment. In France there is also a contract called bail à complant which is a type of lease in which the lessee of a vineyard shares the profits a prendre obtained in the course of using the land with the lessor (art. L. 441-1 C. rur - the French Rural and Marine Fisheries Code consolidated version of 1 September 2017 [Code rural et de la pêche maritime Version consolidée au 1 septembre 2017]). In many legal systems such type of contract does not exist.

Similar long-term contracts for coffee plantations may be found in countries where it is cultivated. In Poland, for instance, no such contracts may be found as the climate is unfavourable for such agricultural produce. And with some exceptions (e.g. orchards), in the majority of cases, one year may be enough to start generating profit from a farm. Under the Polish legal system there is the cultivation contract (agricultural procurement contract) known as umowa kontraktacji which is considered a legal survival of the socialist period (cf. Mańko 2016a, 229-230; 2016b, 78-80). That type of contract, however, is concluded usually for the period of one year. The meaning of the term has evolved. That legal institution is a legal transplant from the Soviet law where it functioned under the name договор контрактачии (Mańko 2016a, 229). Initially the contract was to bind individual farmers (natural persons) with the units of socialized economy. After the political system transformation which took place in Poland in 1989, the range of persons who may conclude that contract has been broadened and nowadays any person may enter into that type of relation with farmers (Mańko 2016a, 229). It should be remembered that

warunkiem przetrwania określonego reliktu prawnego jest jego funkcjonalność wobec realiów nowego ustroju. Funkcjonalność tę można osiągnąć na dwa sposoby: po pierwsze, przez całościową lub częściową kontynuację dotychczasowej funkcji danej instytucji prawnej (jeżeli funkcja ta jest in toto albo częściowo użyteczna także w warunkach nowego ustroju); po drugie, poprzez pełnienie nowych funkcji (użytecznych w warunkach nowego ustroju, których rozpatrywana instytucja prawna $\mathrm{w}$ warunkach poprzedniego ustroju nie pełniła). Możliwe jest też, oczywiście, łączenie sposobu pierwszego z drugim, a zatem może powstać sytuacja, w której dana instytucja prawna pełni częściowo funkcje dotychczasowe, a częściowo nowe. (Mańko 2016 a, 209).

[the condition of survival of a specific legal relic is its functionality towards the realities of the new system. That functionality can be achieved in two ways: firstly, by a total or partial continuation of the previous function of a given legal institution (if this function is in toto or partly useful also under the conditions of the new system); secondly, by performing new functions (useful in the conditions of the new system, which the legal institution under consideration in the conditions of the previous system did not fulfill). It is also possible, of 
course, to combine the first and the second method, and therefore a situation may arise in which the legal institution partially performs the previous and partly new functions.]

Such legal institutions created to meet the needs of participants to legal relations resulting from spatial and temporal conditions are usually the socalled system bound terms (cf. Šarčević 2000), that is to say terms that are typical of a specific legal system and are usually not found in legal systems of other countries or countries belonging to other legal families. Thus, when translating legal texts from the source language belonging to a different legal family than a target language into which the translation needs to be rendered, the translator needs to face the challenge of coping with terms which have no target language oriented equivalents. In such instances the translator on many occasions must either provide descriptive equivalents or coin an equivalent term in order to ensure effective interlingual communication. Sometimes, the translator even resorts to borrowings (either direct or calques) which may result in the so-called legal transplants (Watson 1993).

\section{Linguistics factors resulting from changes in language norms and usage}

Linguistic factors include, for instance, spelling reforms and grammatical changes each language undergoes as a result of usage, etc. As far as the law is concerned, this can be observed when laws are amended. Some laws become repealed very quickly from the moment of their enactment, whilst others remain in force for a long period of time. The latter type of laws are usually amended occasionally. It should be stressed here that some laws may remain in force over a long period of time surviving the change of the political and economic system and becoming "legal survivals" (Mańko 2015a, 2015b).

The notion of 'legal survivals' denotes legal institutions introduced under one historically existing socio-economic and political system (here: actually existing socialism), which were functional towards that system, and which were not removed following a transformation to a different system (Mańko 2016b, 74).

But every natural language is evolving constantly; thus the amendments need to include linguistic changes. Some forms (e.g. grammatical) previously considered unacceptable may start to prevail as a result of ubiquitous usage and they transform into norms, making other forms obsolete. We can observe 
such changes when carrying out terminology comparisons. They usually refer to the transformation of terminology affected by the usage or change of linguistic norms. Sometimes it is fairly easy to demarcate the point in time when a change occurs (if in a given country there is a body responsible for updating linguistic norms). Other changes (e.g. terminological ones) are more evolutionary and may be observed when carrying out detailed corpus linguistic diachronic research.

The examples of terminology transformation resulting from the linguistic norm changes include the following that may be observed in insolvency law. The first regulation on insolvency (the Polish Regulation of the President of the Republic of Poland of 24 October 1934 - Insolvency Law [Rozporządzenie Prezydenta Rzeczpospolitej z dnia 24 października 1934 r. Prawo upadłościowe]) was enacted in 1934 and was not amended until 1991 (hereinafter referred to as the Regulation on Insolvency) ${ }^{1}$. Some forms used in the Regulation on Insolvency became obsolete. For instance in the Regulation on Insolvency, the forms spólnik 'partner' and osoba interesowana 'an interested person, an interested party' may be found. The amendments introduced in 1991 updated the spelling, and the term spólnik was replaced with wspólnik, and osoba interesowana with the form osoba zainteresowana.

In the same Regulation on Insolvency the following terms can be found: (i) czynności upadtego dokonane pod tytutem darmym 'the acts of the insolvent debtor performed free of charge' and (ii) czynności upadtego dokonane pod tytutem obciazliwym 'the acts of the insolvent debtor performed for a fee'. The adjectives darmy 'free of charge' and obciaziliwy 'for payment, for a fee' are no longer used in colloquial, vernacular and official languages. Both terms were obsolete at the time of introducing amendments. Nevertheless they have not been changed until a new law was enacted. In the Act of 28 February 2003 Insolvency and Restructuring Law [Ustawa z dnia 28 lutego 2003 r. - Prawo upadłościowe i naprawcze], the terms have been replaced with czynności prawne upadtego dokonane nieodpłatnie 'the acts in law of the insolvent debtor performed free of charge' and czynności prawne upadtego dokonane odplatnie 'the acts in law of the insolvent debtor performed for a fee' respectively.

\section{Social and custom-related changes}

Social factors cannot be forgotten here as well. As a result of social changes numerous terms have been introduced to legal lexicons in many countries starting with same-sex unions, civil partnerships or same-sexmarriages (cf. Matulewska 2017). 
Analogous changes take place in the wake of less visible social changes. For instance, masculine terms used in legal languages to refer to both males and females are more and more frequently being replaced with gendercorrect counterparts despite the fact that such changes may be highly undesirable from the perspective of communication and especially legal language economy e.g. chairman versus a chairperson. Analogously, political correctness can be observed in the abovementioned gender sensitive language, and through the introduction of terms such as humankind instead of a mankind. Sometimes synonymous strings of terms differing in respect to masculinity and femininity are used e.g. der Richter und die Richterin 'the male and female judge'. On other occasions masculine-tinted terms are replaced with abstract concepts referring to the institutions they represent e.g. a judge is replaced with the court or the minister with the ministry. Mattila (2013, 53) points out that referring in neutral terms to individuals as far as sex is concerned causes numerous problems. On numerous occasions legal texts are made more abstract and textual clumsiness may appear:

In Germany, where the principle of linguistic neutrality is applied in the same way, the doubling of masculine and feminine forms of occupations and titles in some recent laws has been criticized by Eberhard Foth (2007, 410-412). A critical presentation also appear in Walter $(2009,215-224)$ where the author examines, for example, the tension between linguistic neutrality and clumsy style: if - as it has been proposed - the expression Sind Sie in Auszubildender? ['Are you a (masc.) trainee?'] is replaced by the expression: Stehen Sie einem Ausbildungsverhältnis? ['Are you in a training relationship?'], the result is neutral from the standpoint of the sexes, but rather clumsy, typical of Papierdeutsch (Walter 2009: 223) (Mattila 2013, 53, footnote 32).

Such an aspect of the change in society may be seen as a result of the emancipation of women in all spheres of life. In the first version of the Regulation on Insolvency of 1934 the legislator assumed that only men might run businesses and might become insolvent. Thus the term żona upadtego 'insolvent debtor's wife' (art. 30) is used. However, in the course of amendments that term has been replaced with gender neutral matzonek upadtego 'insolvent debtor's spouse'. That change clearly reveals the change in social and business relations and the fact that women gradually and successfully have managed to enter business life and relations.

In the same regulation the term wspólność domowa 'common household property' is used. After the amendments the following terms were introduced in the Regulation wspólność majatkowa 'co-owned property', 
wspólność dorobku 'co-owned property acquired during marriage', majątek wspólny 'co-owned property'. The change also indicates that not only household property may be co-owned by spouses but they both also contribute to the accumulation of other property acquired in the course of marriage.

The translator in such instances must be careful to identify the meanings of such quasi-synonymous terms properly. Otherwise, there is a risk of making a translation mistake and changing the meaning of the target text in respect to the source text. What is more, the translator should also use the terminology which is relevant for the moment of time when the source text was created. The usage of obsolete terminology may only be justified when the source text refers to legal institutions that are obsolete or to the instances when there is no equivalent for a given legal institution of the source language in the target language, apart from the one that has already been repealed from the target language. In such instances the obsolete term may sometimes be used as a target language oriented equivalent satisfying the communication needs of translation recipients.

\section{Politically-influenced changes}

Politically influenced changes (also called ideological cf. Mańko 2014) usually result from transformations in political regimes. Taking into account the fact that the political regimes of Poland have undergone a few such changes within the last century, it is worth analyzing some pieces of legislation enacted at the beginning of such transformations. Therefore, a few examples will be provided from the Decree of 16 November 1945 on Setting Up and the Scope of Activities of the Special Commission for the Fight Against Abuse and Economically Harmful Activities (Dekret z dnia 16 listopada 1945 r. o utworzeniu i zakresie działania Komisji Specjalnej do walki z nadużyciami i szkodnictwem gospodarczym), hereinafter referred to as the Decree (more on the decree cf. Fiedorczyk 2002), and the Polish Civil Code of 1964 of 23 April 1964 [Ustawa Kodeks Cywilny z dnia 23 kwietnia 1964 r.] as amended (before the transformations that took place in 1989) and the above mentioned Regulation on Insolvency law.

Analysing the Decree we may find the following types of crimes that were subject to prosecution by the Special Commission: działanie zwiazane ze wstretem do pracy (literally: 'activities connected with the aversion to work'), szkodnictwo gospodarcze (literally: 'economically harmful activities'), przyłaszczenie mienia spolecznego (literally: 'misappropriation of social property'), powodowanie paniki w celu szkodzenia interesom mas 


\section{Aleksandra Matulewska}

pracujacych (literally: 'causing panic in order to harm the interest of the working masses') which was called in brief propaganda szeptana (literally: 'whispered propaganda'). As a result of the enforcement of the Decree, the language was enriched by the crimes not listed in the Decree but prosecuted by the Special Commission such as bikiniarstwo ('being a member of the Polish subculture similar to the British teddy boys and American greasers'), brakoróbstwo ('shoddy workmanship'), and such like (cf. Zaćmiński 2008, cf. also Fiedorczyk 2002). In that period the term chuligaństwo ('hooliganism') referred not only to rioting, bullying, and vandalism but it was also a crime committed by men wearing longer hair and persons listening to Western music, practicing American life-style, wearing narrow-leg or looseleg trousers, colourful ties with painted pictures, shoes with high soles, and characteristic jackets (Zaćmiński 2016, 89; cf. also Fiedorczyk 2002). At present, wearing colourful clothing at least in many European countries would be considered neither a crime nor an offence, and it would not be penalized in any way. At the same time, however, due to the increasing migration of people and the wave of terrorist attacks, the question arises to what extent societies should be tolerant in respect to customs and traditions concerning clothing. One of the issues recently raised and discussed in the European Union context is the problem of women wearing burkas in European countries and whether it is possible and legal to enact laws and regulations forcing people to abide by the dress codes (cf McCrea 2013; Laborde 2012) even for security reasons and whether such norms are in accordance with human rights (cf. case-law of the European Court of Human Rights ECHR http://www.echr.coe.int/Documents/FS_Religious_Symbols_ENG.pdf).

Political factors cannot be neglected when talking about the language of the law. Political correctness enforces some changes in the language and leads to the introduction of new terms and at the same time the abandonment of others. Some terms cease to be used and consequently become archaic (e.g. mentioned below jednostka gospodarki uspotecznionej 'a unit of socialised economy' - the term used in Poland up to 1989, and abandoned after the transformation of the political regime).

In some situations political transformations result in terminological changes even though the referents remain unchanged. This is usually due to the fact that the signs used to refer to institutions of a former political regime are no longer deemed appropriate, for reasons of promoting a politically changed image or social stigma. For instance, after the collapse of the communist system, the Polish term milicja obywatelska (literally 'the citizens' police') was replaced with the name policja 'the police' (cf. the Act of 6 April 1990 on the Police [ustawa z dnia 6 kwietnia o Policji]). 
The new Act established a new institution but in fact the old institution under the changed name took over the task of fulfilling the functions entrusted to the new institution. The term milicja was associated with the supremacy of the USSR and institutions imposed on Poland by the Soviets. Furthermore, milicja at the communist times was used to suppress social riots against the regime. Consequently, the term milicja is negatively connotated as far as its pragmatic meaning is concerned. For ideological reasons even the colour of uniforms of policemen was changed.

In the abovementioned Polish Law on Insolvency of 1934, the term $k u$ piec 'merchant' is used (cf. e.g. art. 1). After the amendments of that Regulation, the term kupiec 'merchant' was replaced with the term przedsiębiorca 'entrepreneur'. The change resulted from the fact that private businesses were rare during the communist period. State-owned enterprises prevailed. Such enterprises were called przedsiebiorstwo in Polish, 'an enterprise', and the personal noun used in the colloquial language (but absent in the legal language of the communist era) was przedsiębiorca 'an entrepreneur'. Though, it should be borne in mind that the term podmiot gospodarczy 'economic entity' was used at that time as well. The term kupiec 'merchant' referring to persons trading in goods was replaced with a hypernymic term referring to persons carrying out any type of business. It should be pointed out that the change of term from podmiot gospodarczy 'economic entity' to przedsiębiorca 'enterpreneur' was actually a shift in ideological interpellation of subjects (more on such terminological shifts and their underlying ideological premises may be found in Mańko 2014). Such ideological reasons also lead to the anthropomorphisation of some legal institutions in some legal systems. Thus companies which are legal persons are referred to as przedsiebiorca 'entrepreneur' and employing entities having various forms of organization (and encompassing both natural and legal persons) are called pracodawca 'employer' instead of zaktad pracy 'an employing entity' (Mańko 2014, 52).

Since 1989 after the political transition from communism to democracy, the next wave of changes have been observed. The economic conditions also changed significantly with the introduction of the so-called free market. Thus, for instance, the following terms were struck out from the Polish Civil Code of 1964 as amended in 1990: jednostka gospodarki uspolecznionej (lit. 'a unit of socialised economy') (in art. 456), własność ogólnonarodowa (lit. 'nationwide property, all people's property') (in art. 128).

Similarly as in the case of terminology that has transformed due to social factors, the translator needs to take such changes into account. If a given legal institution is no longer in existence (e.g. jednostka gospodarki 


\section{Aleksandra Matulewska}

uspolecznionej 'lit. a unit of socialised economy'), the referent disappears from legal reality, the sign referring to it becomes first obsolete, later on archaic. In such instances when translating from the language in which such social changes have occurred, after applying the chosen equivalent, the translator may resort to footnotes or endnotes in which the change is explained.

\section{Globalization-dependent synonymy}

Some terms enter the legal language as a result of translation of legal texts and the implementation of EU law in national legal systems (cf. Taylor 2011). In recent years the Polish language has been enriched in numerous ways. Some terms are coined on the basis of the terminology already used in English as a language of international communication for the purpose of regulating in a uniform way some commercial relations (e.g. umowa leasingu 'contract of lease with an option to purchase'). Some are borrowed in forms of exotics (e.g. know-how cf. the Act of 26 July 1991 on personal income tax [Ustawa z dnia 26 lipca $1991 \mathrm{r}$. o podatku dochodowym od osób fizycznych] (Polish Official Journal of Laws Dz.U. 1991 No. 80 item 350)), forum shopping (cf. Directive 2001/29/EC of the European Parliament and of the Council of 22 May 2001 on the harmonisation of certain aspects of copyright and related rights in the information society [Dyrektywa 2001/29/WE Parlamentu Europejskiego i Rady z dnia 22 maja 2001 r. w sprawie harmonizacji niektórych aspektów praw autorskich i pokrewnych w społeczeństwie informacyjnym]). They are intentionally introduced and implemented into legal systems. Such terms may appear in laws of the European Union and in the so called soft-laws, that is to say guidelines of international organizations (cf. Abbot and Snidal 2000). If they are introduced in the guidelines of international organizations, they are frequently descriptive in order to make them transnational (e.g. the term coined and used by the United Nations to refer to insolvency practitioners in general is a person (or body) administering a reorganization or liquidation) (Uncitral Model Law on Cross-Border Insolvency http://www.uncitral.org/pdf/english/texts/insolven/insolvency-e.pdf). The advantage of such term is that it does not refer to any legal system, but is a sign which may be interpreted flexibly by the member state of the organization that wants to implement the guidelines into its legal system to facilitate cross-border co-operation, in a given branch of law, between the state in question and other member states. 
In the case of such changes the translator has two options. One is to use the equally descriptive, general and transnational equivalent in the target language and the other one is to replace the term with the target language oriented equivalent. The decision should be conditioned by the translative situation and the communicative needs and requirements of the translation recipient. However, in the majority of cases the application of the transnational descriptive equivalent seems to be appropriate.

Acknowledging that legal translation is a creative, and not mechanical process (Lindroos-Hovinheimo, 2007:372), the CJEU has not implemented any forms of automated, mechanical translation (Gallo, 2006: 190-191), leaving the choice of terminology, style and outlook to the lawyer linguists. The translating activity of a lawyer linguist can be described as a constant switch between the internal and external perspective (cfr. Kozak, 2002:60). Indeed, her task is one of incessantly transacting between the two symbolic universes (cfr. Berger \& Luckmann, 1991:110) - that of the CJEU (and its French-drafted judge-made law) and national law. In order to achieve a fully persuasive translation she must commence from the internal perspective of the CJEU, then switch to the internal perspective of a national lawyer thereby adopting a cognitively external perspective on EU law, but maintaining an emotively internal one (cfr. Kozak, 2002:66) in order to make the best possible choices of terminology and style, and finally switch back to the internal perspective of EU law, not losing sight of the national perspective, in order to verify the consistency of the expected reading by the target audience with the perceived intent of the CJEU judges. (Łachacz \& Mańko 2013, 87).

\section{EU impact on terminological usage}

We may also observe some changes taking place as a result of the impact of the European Union legislation on national legal systems. Under the influence of EU law, the German term Konkurs 'bankruptcy, insolvency' has been replaced with the term Insolvenz 'bankruptcy, insolvency' (Verordnung (Eg) Nr. 1346/2000 des Rates vom 29. Mai 2000 über Insolvenzverfahren) which finds its reflection even in the title of the Regulation in the German version. The term Insolvenz has a wider meaning than Konkurs as the former applies to all sorts of entities who or which are financially troubled whereas the latter to companies. Therefore, the terms are bound by the relation of hypernym (Insolvenz) and hyponym (Konkurs) (cf. Brixel, R. Unterschied zwischen Insolvenz und Konkurs? http://www.sgkanzlei.de/2014/07/unterschied-zwischen-insolvenz-und-konkurs/). 


\section{Aleksandra Matulewska}

The need to distinguish between the civil law tradition of legal systems of continental countries resulted in the need to coin new terms, or to modify the meaning of already existing terms when using English to discuss European Union law (cf. Legislative Drafting http://ec.europa.eu/smartregulation/better_regulation/documents/legis_draft_comm_en.pdf and DGT translation quality guidelines). Thus, the EU uses the term concentration instead of the term merge. In IATE database we may read

A concentration arises either where two or more previously independent undertakings merge (merger), where an undertaking acquires control of another undertaking (acquisition of control), or where a joint venture is created, performing on a lasting basis all the functions of an autonomous economic entity (fullfunction joint venture) (http://iate.europa.eu/FindTermsByLilId.do?lilId=189 9646\&langId=en).

The meaning of the term mortgage has been narrowed down to a burden on immovable property (Šaračević, 2000). Thus the term mortgage in respect to the British common law is hypernymic in respect to the term mortgage in the sense adopted by the European Union. The phenomenon of homography may be observed in that case which in fact makes it necessary for the translator to interpret the meaning of the term in respect to a specific legal system. Without the proper interpretation of the source text term mortgage, the proper translation of the term into many languages will be impossible.

The meaning of the term testament used to be a document used for the transfer of personal property causa mortis. In order to transfer real property the testator was supposed to draft a will or last will and testament as a document by which the Testator directs his or her personal and real property to be distributed at the testator's death. Currently the meaning of the term testament has been broadened by the so-called local and national usage spread by certified translators from civil law countries, and the term is also used as equivalent in meaning with the phrase last will and testament. However, the European Union gives preference to the term will no matter what sort of property is transferred upon one's death (cf Regulation (EU) No. 650/2012 of the European Parliament and of the Council of 4 July 2012 on jurisdiction, applicable law, recognition and enforcement of decisions and acceptance and enforcement of authentic instruments in matters of succession and on the creation of a European Certificate of Succession) http://eur -lex.europa.eu/LexUriServ/LexUriServ.do?uri=OJ:L:2012:201:0107:0134:E $\mathrm{N}: \mathrm{PDF})$. 


\section{Concluding remarks}

The aim of the paper has been to focus on diachronic changes in legal languages and present communication problems resulting from them from intra- and inter-lingual perspectives. To sum up, terminology evolves due to a wide array of reasons. Such changes are unavoidable. What is more, legal texts are interdisciplinary - they are formulated not only in a legal lect but also at least one more specialized lect. That is why the terminology used in them is both legal and non-legal. The law regulates numerous spheres of human activities and therefore must respond to changes that take place in human life.

In general, the observed changes may have the following character:

1. the graphical form remains the same, and the meaning is modelled to suit a changing reality. It is the instance of the occurrence of homography and polysemy with modification of the following meaning:

(a) the meaning may be expanded. It is the instance of the occurrence of hyponym-hypernym relation between the obsolete and up-to-date terms (e.g. umowa kontraktacji 'cultivation contract, agricultural procurement contract');

(b) the meaning may be restricted. It is the instance of the occurrence of hypernym-hyponym relation between the obsolete and up-to-date terms (mortgage under the British common law versus mortgage under the EU law);

(c) the meaning may be to some extent restricted and to some extent expanded. It is the instance of the occurrence of quasi-synonymy (there is no example discussed in the paper meeting the criteria).

2. the sign is changed without the meaning modification. It is the instance of the occurrence of synonymy, though not absolute as one term becomes obsolete (e.g. czynności upadłego dokonane pod tytutem darmym 'the acts of the insolvent debtor performed free of charge' versus czynności prawne upadtego dokonane nieodptatnie 'the acts in law of the insolvent debtor performed free of charge');

3. the sign is changed together with the following meaning modification

(a) the meaning may be expanded. It is the instance of the occurrence of hyponym-hypernym relation between the obsolete and up-to-date terms (e.g. kupiec 'merchant' versus przedsiębiorca 'entrepreneur'; żona upadtego 'insolvent debtor's wife' versus matżonek upadtego 'insolvent debtor's spouse');

(b) the meaning may be restricted. It is the instance of the occurrence of hypernym-hyponym relation between the obsolete and up-to-date 
terms (there is no example discussed in the paper meeting the criteria);

(c) the meaning may be to some extent restricted and to some extent expanded. It is the instance of the occurrence of quasi-synonymy (milicja obywatelska (literally 'the citizens' police') was replaced with the name policja 'the police').

Effective interlingual communication requires the translator to be aware of such changes. Firstly, when translating into the language in which social changes have occurred, the translator needs to know which term is obsolete and which is in use at a given moment in time. Otherwise there is a risk that he or she will use a term that is no longer in use. What is more, such a term may be burdened with a social stigma or communicative inappropriateness. It may even be considered offensive or discriminating against a group of people. In such instances a number of miscommunication problems may occur, not to mention more severe consequences, as in some countries the usage of some abandoned term may even be considered an offence or a crime (e.g. the so-called "N" word in the USA previously used to refer to Americans of African origin). Secondly, when translating from the language in which such social changes have occurred, sometimes there may be a need to supply the information about the diachronic change e.g. in footnotes or endnotes.

In the case of changes, other than political, if the referent still exists but the sign is changed - the old sign becomes obsolete. As already mentioned, there are three more situations: the phenomenon (referent) is modified and the sign referring to it either (i) remains the same despite the modification of reality, or (ii) is modified as well, or (iii) is replaced with a completely new sign. When translating into a language in which such social changes have occurred, the translator should recognize an obsolete term and use an equivalent which is appropriate in a given translative situation. The consequences of applying an obsolete term as a target language oriented equivalent are analogous to those described above when discussing socially conditioned terminological changes. In other instances, the translator should ensure the clarity of meaning of the target text and its correspondence with the source text if need be, resorting to explanations in footnotes or brackets.

\section{N O T E S}

1 The question remains open whether the Polish Regulation on Insolvency of 1934 may be treated as a legal survival in respect to the period of communism in Poland. Nevertheless, some institutions despite the fact that they were not applicable under the socialist regime, have been restored after the political transformation of 1989. Consequently, they 
are in force and in use in legal practice at present. Thus, from that perspective, they may be treated as legal survivals whose existence for some period of time was not needed but after some time in the changed reality they have become useful again and their functionality has resulted in their preservation.

\section{R E F E R E N C E S}

Abbott, K., and D. Snidal. 2000. 'Hard and Soft Law in International Governance.' International Organization 54: 421-456.

Berger, P. L. and T. Luckmann. 1991. The Social Construction of Reality: A Treatise in the Sociology of Knowledge. London: Penguin.

Brixel, R. Unterschied zwischen Insolvenz und Konkurs? Retrieved on 23 December 2017 from http://www.sg-kanzlei.de/2014/07/unterschied-zwischeninsolvenz-und-konkurs/

DGT Translation Quality Guidelines. Directorate-General for Translation (DGT), European Commission. 2015. Retrieved on 1 December 2017 from http://ec. europa.eu/translation/maltese/guidelines/documents/dgt_translation_quali ty_guidelines_en.pdf.

ECHR http://www.echr.coe.int/Documents/FS_Religious_Symbols_ENG.pdf

Fiedorczyk, P. 2002. Komisja Specjalna do Walki z Nadużyciami i Szkodnictwem Gospodarczym 1945-1954. Studium historycznoprawne. Białystok: Temida 2.

Foth E. 2007. Zur geschlechtsneutralen (oder: geschlechtergerechten) Rechtssprache, JR 2007: 410-412.

French Rural and Marine Fisheries Code consolidated version of 1 September 2017 ([Code rural et de la pêche maritime Version consolidée au 1 septembre 2017])

Gallo, G. 2006. Organisation and Features of Translation Activities at the Court of Justice of the European Communities. In B. Pozzo \& V. Jacometti (Eds.), Multilinguism and the harmonisation of European law: 179-196. Alphen aan den Rijn: Kluwer Law International.

General Secretariat of the Council (GSC). 2012. The language service of the General Secretariat of the Council of the European Union. Brussels: Consilium. DOI: $10.2860 / 79193$.

IATE http://iate.europa.eu/FindTermsByLilId.do?lilId=1899646\&langId=en

Joint Practical Guide of the European Parliament, the Council and the Commission for persons involved in the drafting of European Union legislation. Retrieved on 2 December 2017 from http://eur-lex.europa.eu/content/techleg/ENlegislative-drafting-guide.pdf.

Kańska, K. 2004. 'Pojęcie konsumenta w kodeksie cywilnym na tle tendencji europejskich'. 13 (1) Kwartalnik Prawa Prywatnego.

Kozak, A. 2002. Granice prawnicze władzy dyskrecjonalnej [Limits of the Discretionary Power of Lawyers]. Wrocław: Kolonia Limited. 
Laborde, C. 2012. 'State Paternalism and Religious Dress'. International Journal of Constitutional Law, vol. 10 (2): 398-410.

Eachacz O., and R. Mańko. 2013. 'Multilingualism at the Court of Justice of the European Union: Theoretical and Practical Aspects'. Studies in Logic, Grammar and Rhetoric 34: 75-92.

Legislative Drafting Retrieved on 14 December 2017 from http://ec.europa.eu/smart -regulation/better_regulation/documents/legis_draft_comm_en.pdf

Lindroos-Hovinheimo, S. 2007. 'On the Indeterminacy of Legal Translation' in T. Wilhelmsson, E. Paunio and A. Pohjolainen (eds.) Private Law and the Many Cultures of Europe: 367-384. Alphen aan den Rijn: Kluwer Law International.

Malinowski B. 1961. A Scientific Theory of Culture and Other Essays. New York: Oxford University Press.

Mańko, R. 2014. 'Koncepcja interpelacji ideologicznej a krytyczny dyskurs o prawie' [The Notion of Ideological Interpellation and Critical Discourse on Law], Archiwum Filozofii Prawa i Filozofii Spolecznej 8: 41-54.

Mańko, R. 2015a. 'Relikty w kulturze prawnej. Uwagi metodologiczne na tle pozostałości epoki socjalizmu realnego w polskim prawie prywatnym', Przeglad Prawa i Administracji 102: 185-208.

Mańko, R. 2015b. 'Legal Survivals: A Conceptual Tool for Analysing PostTransformation Continuity of Legal Culture' in: J. Rozenfelds (ed.) Tiesību efektivitāte postmodernā sabiedrībō: 16-27. Riga: Latvia University Press.

Mańko, R. 2015c. 'Reality is for Those Who Cannot Sustain the Dream: Fantasies of Selfhood in Legal Texts', Wrocław Review of Law, Administration \& Economics 5.1: 24-47.

Mańko, R. 2016a. Wybrane relikty prawne epoki socjalizmu realnego w polskim prawie cywilnym - analiza zmiany funkcji społecznej instytucji prawnych w następstwie transformacji ustrojowej [Selected Legal Survivals of the Period of Actually Existing Socialism in Polish Civil Law: An Analysis of the Change of Social Function of Legal Institutions as a Consequence of Systemic Transformation]. Studia Iuridica 66: 207-235.

Mańko, R. 2016b. 'Demons of the Past? Legal Survivals of the Socialist Legal Tradition in Contemporary Polish Private Law' in R. Mańko, C. Cercel and A. Sulikowski (eds) Law and Critique in Central Europe: Questioning the Past, Resisting the Present: 66-89. Oxford: Counterpress.

Mattila, H. 2013. Comparative Legal Linguistics. England: Ashgate.

Matulewska, A. 2013. Legilinguistic translatology. A parametric approach to legal translation. Linguistic Insights Vol. 171. Bern: Peter Lang.

Matulewska, A. 2017. Socially Induced Changes in Legal Terminology. Studies in Logic, Grammar and Rhetoric 49 (1): 153-173. DOI: https://doi.org/10.1515 /slgr-2017-0010.

McCrea, R. 2013. 'The Ban on theVeil and European Law', Human Rights Law Review 13 (1): 57-97. 
Šarčević, S. 2000. New Approach to Legal Translation. The Hague: Kluwer Law International.

Taylor, S. 2011. 'The European Union and National Legal Languages: an Awkward Partnership?' Revue française de linguistique appliquée vol. xvi, (1): 105-118. https://www.cairn.info/revue-francaise-de-linguistiqueappliquee-2011-1-page $-105 . h t m$.

Walter, T. 2009. Kleine Stilkunde für Juristen. 2nd ed. Munich: Verlag C. H. Beck.

Watson A. 1993. Legal Transplants: An Approach to Comparative Law. AthensLondon: University of Georgia Press.

Zaćmiński, A. 2008. Przestępstwa polityczne w orzecznictwie Komisji Specjalnej do Walki z Nadużyciami i Szkodnictwem Gospodarczym 1950-1954, Pamięć i Sprawiedliwość: Biuletyn Gtównej Komisji Badania Zbrodni przeciwko Narodowi Polskiemu Instytutu Pamięci Narodowej, no 1: 321-343. Retrieved April 2015 from the website of http://www.polska1918-89.pl/pdf/przestepst wa-polityczne-w-orzecznictwie-komisji-specjalnej-do-walki-z-,3402.pdf.

Zaćmiński, A. 2016. "Poena sine lege" - czyny chuligańskie w orzecznictwie Komisji Specjalnej do Walki z Nadużyciami i Szkodnictwem Gospodarczym (19511954). Dzieje Najnowsze, vol. 48, no. 1: 83-112. DOI: http://dx.doi.org/10.12 775/DN.2016.1.06. Retrieved April 2015 from the website of http://www.ap cz.pl/czasopisma/index.php/DN/article/view/DN.2016.1.06/9383.

Act of 26 July 1991 on personal income tax [Ustawa z dnia 26 lipca 1991 r. o podatku dochodowym od osób fizycznych] (Polish Official Journal of Laws Dz.U. of 1991 No. 80 item 350. Retrieved 15 December 2017.

Act of 28 February 2003 insolvency and restructuring law [Ustawa z dnia 28 lutego 2003 r. - Prawo upadłościowe i naprawcze]. Retrieved January 2017 from http://isap.sejm.gov.pl/DetailsServlet?id=WDU20030600535.

Act of 28th July 2005 on the amendment of the Code of Civil Procedure Ustawa z dnia 28 lipca 2005 r. o zmianie ustawy - Kodeks postępowania cywilnego oraz niektórych innych ustaw]. Retrieved September 2017 from [http://isap. sejm.gov.pl/DetailsServlet?id=WDU20051721438+2005\%2412\%2410\&min $=1$

Act of 6 April 1990 on the Police [Ustawa z dnia 6 kwietnia o Policji] (Polish Official Journal of Laws Dz.U. of 1990, No. 30, item 179) Retrieved 22 December 2017 from http://prawo.sejm.gov.pl/isap.nsf/download.xsp/WDU19900300179/O /D19900179.pdf.

Decree of 16 November 1945 on Setting Up and the Scope of Activities of the Special Commission for the Fight Against Abuse and Economically Harmful Activities [Dekret z dnia 16 listopada 1945 r. o utworzeniu i zakresie działania Komisji Specjalnej do walki z nadużyciami i szkodnictwem gospodarczym]. Retrieved January 2017 from http://dziennikustaw.gov.pl/du/1945/s/53/302.

Directive 2001/29/EC of the European Parliament and of the Council of 22 May 2001 on the harmonisation of certain aspects of copyright and related rights 
in the information society [Dyrektywa 2001/29/WE Parlamentu Europejskiego i Rady z dnia 22 maja 2001 r. w sprawie harmonizacji niektórych aspektów praw autorskich i pokrewnych w społeczeństwie informacyjnym] Retrieved 22 December 2017 from http://eur-lex.europa.eu/legal-content/PL /TXT/?qid=1514299122323\&uri=CELEX:32001L0029.

European Council Regulation (EC) No 1346/2000 on insolvency proceedings. Retrieved June 2013 from Eur-Lex http://eur-lex.europa.eu/LexUriServ/Lex UriServ.do?uri=OJ:L:2000:160:0001:0018:en:PDF.

French Rural and Marine Fisheries Code consolidated version of 1 September 2017 ([Code rural et de la pêche maritime Version consolidée au 1 septembre 2017]). Retrieved September 2017 from https://www.legifrance.gouv.fr/affich Code.do;jsessionid=F63BE66D7A97E01402A7A8280DD0B8B7.tpdila18v_3 ?cidTexte $=$ LEGITEXT000006071367\&dateTexte $=20170908$.

Legislative Drafting A Commission Manual. Retrieved on 12 December 2017 from http://ec.europa.eu/smart-regulation/better_regulation/documents/legis_ draft_comm_en.pdf.

Polish Civil Code of 1964 of 23 April 1964 [Ustawa Kodeks Cywilny z dnia 23 kwietnia 1964 r.]. Retrieved April 2015 from the website of Kancelaria Sejmu http://isap.sejm.gov.pl/DetailsServlet?id=WDU19640160093.

Polish Civil Code of 1964 of 23 April 1964 [Ustawa Kodeks Cywilny z dnia 23 kwietnia 1964 r. z późniejszymi zmianami] as amended. Retrieved January 2017 from http://isap.sejm.gov.pl/DetailsServlet?id=WDU19640160093.

Polish Regulation of the President of the Republic of Poland of 24 October 1934 - Insolvency Law [Rozporządzenie Prezydenta Rzeczpospolitej z dnia 24 października 1934 r. - Prawo upadłościowe]) Retrieved January 2017 from http://isap.sejm.gov.pl/DetailsServlet?id=WDU19340930834.

Polish Regulation of the President of the Republic of Poland of 24 October 1934 - Insolvency Law as amended in 1991-1995 [Rozporządzenie Prezydenta Rzeczpospolitej z dnia 24 października 1934 r. - Prawo upadłościowe z późniejszymi zmianami]) Retrieved January 2017 from http://isap.sejm.gov. pl/DetailsServlet?id=WDU19340930834.

Regulation (EU) No 650/2012 on jurisdiction, applicable law, recognition and enforcement of decisions and acceptance and enforcement of authentic instruments in matters of succession and on the creation of a European Certificate of Succession Retrieved on 17 December 2017 from http:// eur-lex.europa.eu/LexUriServ/LexUriServ.do?uri=OJ:L:2012:201:0107:0134 :EN:PDF.

Uncitral Model Law on Cross-Border Insolvency Retrieved on 23 December 2017 from http://www.uncitral.org/pdf/english/texts/insolven/insolvency-e.pdf.

Verordnung (Eg) Nr. 1346/2000 des Rates vom 29. Mai 2000 über Insolvenzverfahren. Retrieved June 2013 from Eur-Lex Retrieved 7 June 2017 from http://eur-lex.europa.eu/LexUriServ/LexUriServ.do?uri=OJ:L:2000:160:00 01:0018:de:PDF. 